\title{
Unclogging Seed Borne Pathogens to Prevent Diseases in Capsicum
}

\author{
Suryapal Singh ${ }^{1 *}$ and Harshita Singh ${ }^{2}$ \\ ${ }^{1}$ Department of Seed Science and Technology, Dr. Y.S. Parmar University of Horticulture \\ and Forestry, Nauni, Solan (HP) 173230 \\ ${ }^{2}$ Department of Vegetable Science, CCSHAU, Hisar, India \\ *Corresponding author
}

\section{A B S T R A C T}

\section{Keywords}

Hot water seed treatment, Bell pepper, Seed microflora, Disease incidence and Capsicum annuum

Article Info

Accepted:

15 April 2020 Available Online: 10 May 2020
The present investigations was carried out to study the effect of hot water seed treatment comprised of different ranges of temperature (47-49, 50-52 and 53-55 ${ }^{\circ} \mathrm{C}$ ) and discrete duration of time (30, 45 and 60 min.). The seeds of bell pepper and their most important seed-borne pathogens (Alternaria spp., Curvuleria spp., Penicillium spp., Fusarium spp. Colletotrichum spp.) have been investigated in laboratory. Thee numbers of infected seeds were observed and recorded daily and per cent incidence was evaluated. Furthermore, per cent ungerminated seeds and incidence of various diseases like, damping-off, anthracnose, wilt, cercospora leaf spot and virus attack was recorded in nursery as well as in field under protected cultivation. Under in vitro conditions, the hot water treated seed with temperature $50-52^{\circ} \mathrm{C}$ for $30 \mathrm{~min}$. showed significantly lower seed microflora (\%) as compared to untreated seed (control). In nursery condition, the hot water treated seed, same temperature $50-52^{\circ} \mathrm{C}$ for 30 minutes showed lower damping-off and virus incidence as compared to control with 22.75 per cent post emergence damping-off and 5.56 per cent respectively. Though, the incidence of damping off and virus attack is minimum in case of the hot water treated seed same temperature $53-55^{\circ} \mathrm{C}$ for $60 \mathrm{~min}$. i.e. 5.47 per cent and 1.11 per cent respectively but this high temperature for such long time have strongly affected germination. That's why ungerminated seed percentage in case of is hot water treated with $53-55^{\circ} \mathrm{C}$ for $60 \mathrm{~min}$. is 41.11 which is significantly very high compared to the hot water treated with $50-52^{\circ} \mathrm{C}$ for 30 minutes i.e. 12.22 per cent. Under protected condition the hot water treated with $50-52^{\circ} \mathrm{C}$ for $30 \mathrm{~min}$. showed lower incidence of diseases like anthracnose, cercospora leaf spot, wilt and virus as compared to control. It may be concluded that hot water seed treatment at $50-52^{\circ} \mathrm{C}$ for $30 \mathrm{~min}$. proved effective in reducing the incidence of diseases like damping-off, anthracnose, cercospora leaf spot and viruses in bell pepper cultivar Solan Bharpur without any ill effect on the germination of seeds.

\section{Introduction}

Bell pepper (Capsicum annuиm L.), also known as sweet pepper, capsicum or Shimla mirch, belongs to family solanaceae. It is a high value vegetable and an important cash crop grown throughout the world. It has attained a status of high value crop in recent 
years because of its delicacy and pleasant flavour coupled with rich content of ascorbic acid and other vitamins and minerals (Agarwal et al., 2007). Bell pepper is mainly cultivated as summer and rainy season crop. Because of high humidity and soil moisture coupled with moderate temperature, the incidence of various diseases is high. Some diseases are seed borne in nature viz., anthracnose (Colletotrichum capsici), Cercospora leaf spot (C. capsici), bacterial spot (Xanthomonas campestris pv. vesicatoria), Bacterial wilt (Pseudomonas solanacearum), Bacterial canker (Clavibacter michiganensis) and viruses like Tomato spotted wilt virus (TSWV). To avoid the occurrence of such diseases, seed treatment with various chemicals has been recommended from time to time (Gupta and Thind, 2006). But in present day agriculture, use of chemicals for crop production is discouraged. Seed borne diseases of bell pepper are considered as alarming problem in organic farming systems because of the nonecofriendly chemical control methods. Hence, other alternative treatments for disease control have been developed and hot water treatment is one of them.

Hot water soaking is a very old practice but has revived in this era of organic farming to control many seed-borne diseases by using temperatures hot enough to kill the organism but not quite hot enough to kill the seed and it is still being used as a very effective alternative (Floyd, 2005; Muniz, 2001). Hot water seed treatment is thermo physical method of plant protection. At the end of the 19th century, for control of control loose smut (Ustilago nuda) the hot water seed treatment was applied to in cereals (Jensen, 1888). During storage of oak seed, hot water seed treatment has been recommended against the fungus Ciboria batschiana (Natzke, 1997). Further examples for application of the method are shown by Baker (1962),
Gabrielson (1983), Hoffmann et al., (1994) and Jahn et al., (2000). Hot water treatment is of more importance for organic farming (Trueman and Wick, 1996). It could also become an alternative method for conventional farming especially in case of failure of chemicals permitted for seed treatment. The present investigation was designed to study the effect of different temperature and time combinations of hot water seed treatment on incidence of diseases and seed microflora in bell pepper.

\section{Materials and Methods}

The present experiment was carried out at Experimental Farm and Laboratory of Department of Seed Science and Technology, Dr YS Parmar University of Horticulture and Forestry, Solan. The experimental farm of Department of Seed Science and Technology is located at an altitude of 1183 meters above mean sea level with latitude of $30.51^{\circ} \mathrm{N}$ and longitude of $77.09^{\circ} \mathrm{E}$ the mid- hill zone of Himachal Pradesh, India observed with GARMIN'S GPS 12 Personal Navigator. The soil texture of polyhouse was loam to clay loam having $\mathrm{pH}$ ranging from 6.85-7.05. The healthy, disease free, bold and uniform seeds of bell pepper cv. Solan Bharpur, were obtained from Department of Seed Science and Technology, Dr. Y.S. Parmar University of Horticulture and Forestry, Nauni, Solan (H.P.). The obtained seeds were treated with hot water in automatically controlled hot water bath tub at different temperature range for discrete time period (Table 1). The in vitro experiment was laid in Completely Randomized Block Design with four replications taking 50 seeds per replication. The experiments in nursery condition and protected condition were both laid in Randomized Block Design with ten treatments replicated three times taking 30 seedlings and 6 plants per replication respectively. 
Hot water bath works automatically controlling temperature with time. Firstly seeds were soaked in normal water for 15 min. wrapped in muslin cloth. Then, poured about 3 1. water in the device and it was connected with electricity. With the help of heater coil, the device was heated, with the time and thermostat bulb the device was regulated to the desired temperatures such as (47- 49), (50-52) and (53-55) ${ }^{\circ} \mathrm{C}$ was maintained. With the thermometer the desired temperature was denoted. Fixing temperature and time Thermostat bulb was regulated to fix the desired temperature. At the end of the treatment, seeds were taken out of the hot water bath and spread on blotter paper. After that the blotter paper with seeds was placed in shade for drying of seeds. Then, the seeds were used for test. Seed microflora (\%) was observed by following standard Petri plate method as per the ISTA. The seeds of bell pepper were kept in Petri plates (50 seeds per replication). These plates with seeds incubated at $25^{\circ} \mathrm{C}$ temperatures for 14 days. Numbers of infected seed were observed and per cent incidence was observed by following the method:-

Seed microflora $\%=($ No. of infected seed $/$ Total no. of seed) x 100

Ungerminated seed (\%) was also recorded in nursery by following formula:

Ungerminated seed $(\%)=$ (Ungerminated seeds / Total number of seeds planted) x 100

Incidence of damping-off, virus attack and disease incidence was recorded in nursery and field under protected condition by using the following formula:

Disease incidence $(\%)=($ Number of diseased seedlings per plot / Total number of seedlings per plot) $\mathrm{x} 100$
The statistical analysis of the data generated was done as per design of the experiment as suggested by Gomez and Gomez (1984).

\section{Results and Discussion}

Seed contamination with microflora (Alterneria spp., Curvuleria spp., Penicilium spp., Fusarium spp., Colletotrichum spp.) and total microflora was predominant in control group $(10.00,3.00,12.00,11.00,7.00$ and $43.00 \%$, respectively), whereas the least predominant microflora per cent $(1.00,1.00$, $3.00,2.00,0.00$ and 7.00, respectively) were recorded in seeds soaked at $53-55{ }^{\circ} \mathrm{C}$ for 60 $\min \left(\mathrm{T}_{3} \mathrm{t}_{3}\right)$. Seeds soaked at $50-52^{\circ} \mathrm{C}\left(\mathrm{T}_{2} \mathrm{t}_{1} /\right.$ $\begin{array}{llll}\mathrm{T}_{2} \mathrm{t}_{2} / & \left.\mathrm{T}_{2} \mathrm{t}_{2}\right) & \text { showed intermediate values }\end{array}$ between the two extremes.

The temperatures and durations of hot water treatment resulted in significant reduction in the mean incidence of various fungi as the fungi did not tolerate the higher temperature range. Reported $50-52^{\circ} \mathrm{C}$ temperature for 15 $30 \mathrm{~min}$. most suitable against important seed microflora in solanaceous crops like brinjal. Similarly Nega et al., (2003) reported that heating carrot seed to $54^{\circ} \mathrm{C}$ in water for 20 minutes completely eradicated $A$. dauci found that hot water treatment at $53^{\circ} \mathrm{C}$ for 10 to 30 min of carrot, cabbage, celery, parsley, and lamb's lettuce seed controlled Alterneria dauci, A. radicina, A. alternata, and $A$. brassicicola.

Hermansen et al., (1999) reported that heating carrot seed to $54^{\circ} \mathrm{C}$ in water for $20 \mathrm{~min}$ completely eradicated $A$. dauci.

Temple et al., (2013) found hot water treatment at $50^{\circ} \mathrm{C}$ for $20 \mathrm{~min}$. can significantly reduce incidence of fungus (Cladosporium spp., Fusarium spp., and Alternaria spp.) (Table 2 and 3). 
Table. 1 Treatment details

\begin{tabular}{|c|c|c|}
\hline Treatment & Temperature $\left.\mathbf{(}^{\mathbf{}} \mathbf{C}\right)$ & Time $(\mathbf{m i n})$ \\
\hline $\mathbf{T}_{\mathbf{1}} \mathbf{t}_{\mathbf{1}}$ & $47-49$ & 30 \\
\hline $\mathbf{T}_{\mathbf{1}} \mathbf{t}_{\mathbf{2}}$ & $47-49$ & 45 \\
\hline $\mathbf{T}_{\mathbf{1}} \mathbf{t}_{\mathbf{3}}$ & $47-49$ & 60 \\
\hline $\mathbf{T}_{\mathbf{2}} \mathbf{t}_{\mathbf{1}}$ & $50-52$ & 30 \\
\hline $\mathbf{T}_{\mathbf{2}} \mathbf{t}_{\mathbf{2}}$ & $50-52$ & 45 \\
\hline $\mathbf{T}_{\mathbf{2}} \mathbf{t}_{\mathbf{3}}$ & $50-52$ & 60 \\
\hline $\mathbf{T}_{\mathbf{3}} \mathbf{t}_{\mathbf{1}}$ & $53-55$ & 30 \\
\hline $\mathbf{T}_{\mathbf{2}} \mathbf{t}_{\mathbf{2}}$ & $53-55$ & 45 \\
\hline $\mathbf{T}_{\mathbf{3}} \mathbf{t}_{\mathbf{3}}$ & $53-55$ & 60 \\
\hline $\mathbf{T}_{\mathbf{0}}$ (control) & \multicolumn{2}{|c|}{ Untreated seeds } \\
\hline
\end{tabular}

Table.2 Effect of hot water seed treatment on seed microflora in bell pepper cv. Solan Bharpur

\begin{tabular}{|c|c|c|c|c|c|c|}
\hline Treatments & \multicolumn{5}{|c|}{ Seed microflora (\%) } \\
\cline { 2 - 7 } & $\begin{array}{c}\text { Alterneria } \\
\text { spp. }\end{array}$ & $\begin{array}{c}\text { Curvuleri } \\
\text { a spp. }\end{array}$ & $\begin{array}{c}\text { Peniciliu } \\
\text { m spp. }\end{array}$ & $\begin{array}{c}\text { Fusarium } \\
\text { spp. }\end{array}$ & $\begin{array}{c}\text { Colletotrichum } \\
\text { spp. }\end{array}$ & $\begin{array}{c}\text { Total Seed } \\
\text { microflora }\end{array}$ \\
\hline $\mathbf{T}_{\mathbf{1}} \mathbf{t}_{\mathbf{1}}$ & 7.00 & 2.00 & 9.00 & 8.00 & 4.00 & 30.00 \\
\hline $\mathbf{T}_{\mathbf{1}} \mathbf{t}_{\mathbf{2}}$ & 7.00 & 2.00 & 7.00 & 6.00 & 3.00 & 25.00 \\
\hline $\mathbf{T}_{\mathbf{1}} \mathbf{t}_{\mathbf{3}}$ & 6.00 & 2.00 & 5.00 & 5.00 & 3.00 & 21.00 \\
\hline $\mathbf{T}_{\mathbf{2}} \mathbf{t}_{\mathbf{1}}$ & 6.00 & 2.00 & 4.00 & 3.00 & 1.00 & 16.00 \\
\hline $\mathbf{T}_{\mathbf{2}} \mathbf{t}_{\mathbf{2}}$ & 4.00 & 1.00 & 4.00 & 4.00 & 1.00 & 14.00 \\
\hline $\mathbf{T}_{\mathbf{2}} \mathbf{t}_{\mathbf{3}}$ & 4.00 & 1.00 & 4.00 & 3.00 & 1.00 & 13.00 \\
\hline $\mathbf{T}_{\mathbf{3}} \mathbf{t}_{\mathbf{1}}$ & 4.00 & 1.00 & 4.00 & 3.00 & 0.00 & 12.00 \\
\hline $\mathbf{T}_{\mathbf{3}} \mathbf{t}_{\mathbf{2}}$ & 2.00 & 1.00 & 4.00 & 2.00 & 0.00 & 9.00 \\
\hline $\mathbf{T}_{\mathbf{3}} \mathbf{t}_{\mathbf{3}}$ & 1.00 & 1.00 & 3.00 & 2.00 & 0.00 & 7.00 \\
\hline $\mathbf{T}_{\mathbf{0}}$ & 10.00 & 3.00 & 12.00 & 11.00 & 7.00 & 43.00 \\
\hline $\mathbf{C D} \mathbf{a t} \mathbf{5} \%$ & 1.07 & $\mathrm{NS}$ & 0.59 & 0.94 & 0.65 & 3.74 \\
\hline
\end{tabular}

Table.3 Effect of hot water seed treatment on disease incidence in bell pepper cv. Solan Bharpur under nursery conditions

\begin{tabular}{|c|c|c|c|}
\hline Treatments & \multicolumn{3}{|c|}{ Characters } \\
\hline & Ungerminated seeds (\%) & Damping-off (post emergence) (\%) & Virus (\%) \\
\hline $\mathbf{T}_{\mathbf{1}} \mathbf{t}_{\mathbf{1}}$ & 31.11 & 54.84 & 15.55 \\
\hline $\mathbf{T}_{\mathbf{1}} \mathbf{t}_{\mathbf{2}}$ & 25.56 & 35.77 & 13.33 \\
\hline $\mathbf{T}_{\mathbf{1}} \mathbf{t}_{\mathbf{3}}$ & 17.78 & 25.53 & 10.00 \\
\hline $\mathbf{T}_{\mathbf{2}} \mathbf{t}_{\mathbf{1}}$ & 12.22 & 22.75 & 5.56 \\
\hline $\mathbf{T}_{\mathbf{2}} \mathbf{t}_{\mathbf{2}}$ & 23.33 & 23.16 & 4.44 \\
\hline $\mathbf{T}_{\mathbf{2}} \mathbf{t}_{\mathbf{3}}$ & 27.78 & 15.34 & 3.33 \\
\hline $\mathbf{T}_{\mathbf{3}} \mathbf{t}_{\mathbf{1}}$ & 26.67 & 18.07 & 3.33 \\
\hline $\mathbf{T}_{\mathbf{3}} \mathbf{t}_{\mathbf{2}}$ & 35.55 & 7.034 & 2.22 \\
\hline $\mathbf{T}_{\mathbf{3}} \mathbf{t}_{\mathbf{3}}$ & 41.11 & 5.47 & 1.11 \\
\hline $\mathbf{T}_{\mathbf{0}}$ & 30.00 & 63.59 & 23.33 \\
\hline $\mathbf{C D} \mathbf{a t} \mathbf{5}$ & 3.65 & 7.00 & 0.86 \\
\hline
\end{tabular}


Table.4 Effect of hot water seed treatment on disease incidence in bell pepper cv. Solan Bharpur under protected conditions

\begin{tabular}{|c|c|c|c|c|}
\hline \multirow{2}{*}{ Treatments } & \multicolumn{4}{|c|}{ Disease incidence (\%) } \\
\cline { 2 - 3 } & Anthracnose & $\begin{array}{c}\text { Cercospora } \\
\text { leaf spot }\end{array}$ & Wilt & Virus \\
\hline $\mathbf{T}_{\mathbf{1}} \mathbf{D}_{\mathbf{1}}$ & 23.18 & 38.89 & 0.00 & 27.78 \\
\hline $\mathbf{T}_{\mathbf{1}} \mathbf{D}_{\mathbf{2}}$ & 19.79 & 27.78 & 0.00 & 22.22 \\
\hline $\mathbf{T}_{\mathbf{1}} \mathbf{D}_{\mathbf{3}}$ & 11.27 & 11.11 & 0.00 & 16.67 \\
\hline $\mathbf{T}_{\mathbf{2}} \mathbf{D}_{\mathbf{1}}$ & 9.59 & 16.67 & 0.00 & 11.11 \\
\hline $\mathbf{T}_{\mathbf{2}} \mathbf{D}_{\mathbf{2}}$ & 10.63 & 11.11 & 0.00 & 11.11 \\
\hline $\mathbf{T}_{\mathbf{2}} \mathbf{D}_{\mathbf{3}}$ & 7.59 & 5.56 & 0.00 & 5.56 \\
\hline $\mathbf{T}_{\mathbf{3}} \mathbf{D}_{\mathbf{1}}$ & 7.62 & 5.56 & 0.00 & 5.56 \\
\hline $\mathbf{T}_{\mathbf{3}} \mathbf{D}_{\mathbf{2}}$ & 4.97 & 0.00 & 0.00 & 5.56 \\
\hline $\mathbf{T}_{\mathbf{3}} \mathbf{D}_{\mathbf{3}}$ & 3.16 & 0.00 & 0.00 & 5.56 \\
\hline $\mathbf{T}_{\mathbf{0}}$ & 24.23 & 44.44 & 5.56 & 44.44 \\
\hline $\mathbf{C D} \mathbf{a t} \mathbf{5} \%$ & 0.30 & 19.55 & $\mathrm{NS}$ & 20.46 \\
\hline
\end{tabular}

Disease incidence and ungerminated seed (\%) under nursery conditions

Significantly higher ungerminated seeds $(41.11 \%)$ were recorded, when seeds were soaked at 53-55 ${ }^{\circ} \mathrm{C}$ for $60 \mathrm{~min}\left(\mathrm{~T}_{3} \mathrm{t}_{3}\right)$ and lowest proportion of ungerminated seeds $(12.22 \%)$, when soaked at $50-52^{\circ} \mathrm{C}$ for $30 \mathrm{~min}$ $\left(\mathrm{T}_{2} \mathrm{t}_{1}\right)$. Seedlings kept as control had intermediate proportion of ungerminated seeds $(30.00 \%)$. In contrast, the per cent damping off (post-emergence) was highest in control groups $(63.59 \%)$ and lowest $(5.47 \%)$ in seeds were soaked at $53-55^{\circ} \mathrm{C}$ for $60 \mathrm{~min}$ (T3t3). Seeds soaked at $50-52^{\circ} \mathrm{C}\left(\mathrm{T}_{2} \mathrm{t}_{1} / \mathrm{T}_{2} \mathrm{t}_{2} /\right.$ $\mathrm{T}_{2} \mathrm{t}_{2}$ ) showed intermediate values between the two extremes. Similarly, the presence of virus (\%) was shown to be highest in control (23.33 $\%)$ and lowest $(1.11 \%)$ in seeds soaked at 53$55^{\circ} \mathrm{C}$ for $60 \mathrm{~min}(\mathrm{~T} 3 \mathrm{t} 3)$. In case of $\mathrm{T}_{2} \mathrm{D}_{1}$ (seeds soaked at $50-52{ }^{\circ} \mathrm{C}$ for $30 \mathrm{~min}$ ) incidence recorded due to post emergence damping-off and virus (\%) was 22.75 per cent and 5.56 per cent respectively which was significantly less as compared to control. Hot water seed treatment has been used to control many seed borne diseases by using temperature hot enough to kill organisms but not quite hot to kill the seed (Miller,2005). It is believed that hot water treatment may activate pathogenesis-related (PR) proteins. PR proteins coded by host plant genes are induced by pathogen infection or related situations, and are thought to play a major role in plant defence responses against a wide variety of pathogens Van Loon and Van Strien, 1999). Among the PR proteins, the most characterized enzymes are those of group 2 that have $\beta$-1, 3-glucanase activity (Kauffmann et al., 1987) and group 3 that have chitinase activity and both hydrolyze polymers of fungal cell walls and are, therefore, thought to be involved in the plant defence mechanism against fungal infection (Schlumbaum et al., 1986, Collinge et al., 1993). These enzymes were capable of inducing plant resistance against pathogen infection in transgenic plants which over express chitinase and $\beta$-1, 3-glucanase genes (Zhu et al., 1994; Jach et al., 1995). Hot water temperature at $50-53{ }^{\circ} \mathrm{C}$ has found as the optimum ranged for reducing various seed borne diseases including fungi, bacteria and viruses of vegetable crops and other crops by 
earlier workers (Nega et al., 2003; Nandini and Kulkarni, 2015). The use of hot water treatments to control seed-borne diseases is regarded as very efficient in destroying pathogens borne both, outside the testa, such as TSWV (Edmund and Pottorff, 2009) and inside the seed testa (Miller and Ivey, 2004;). Zitter et al., (1989) have reported that hot water seed treatment at $50-55{ }^{\circ} \mathrm{C}$ for $25-30$ min. controlled viruses affecting tomato, such as the Tomato mosaic virus (TMV), Pepino mosaic virus (PMV), Tobacco mosaic virus (YMV) and Tomato spotted wilt virus (TSWV). Winter et al., (1997) compared hot water treatments $\left(52{ }^{\circ} \mathrm{C}\right.$ for $10 \mathrm{~min}$.) of cereal seeds were with seed fungicides and found that it was equally effective in controlling damping-off disease. The mode of action of hot water seed treatment could be direct killing of seed borne inoculum in and on the seed.

\section{Disease incidence under protected conditions}

Hot water treatment of seeds has significant effect on disease incidence under protected condition (Table 4). Incidence (\%) of antracnose, cercospora leaf spot, wilt and presence of virus was highest in control (24.23, 44.44, 5.56, and 44.44, respectively) and lowest in T3t3 (4.97, 0.00, 0.00 and 5.56, respectively). However, in the remaining treatment-time combinations, the values remained intermediate between two extremes. The probable reasons behind the reduced incidence of various diseases after hot water seed treatment were found to be the killing of seed borne inoculum of these pathogens due to increased temperature. Although, elimination of seed microflora was effective, seed quality i.e. percent ungerminated seeds deteriorated with higher temperature-time combinations. Muniz (2001) reported Hot water treatment as potent practice to neutralise the seed borne organisms but not quite enough to kill the seed. Similarly, Miller and Ivey (2004) and Miller and Ivey (2005) reported reduction in the occurrence of anthracnose, bacterial canker, bacterial spot, bacterial wilt and bacterial speck after treatment of seeds of tomato and bell pepper with hot water at 50 to $55^{\circ} \mathrm{C}$ for 25 to 30 minutes. Treatments of bell pepper seed with hot water at $45^{\circ} \mathrm{C}$ for $15 \mathrm{~min}$ or $53^{\circ} \mathrm{C}$ for 4 min prior to storage at $8^{\circ} \mathrm{C}$ reduced the incidence of fungal infections (Aguilar et al., 1998). This method is more eco-friendly and effective compared to chemical treatment, however, they can cause the loss of seed viability (Meah, 2004). Seed of okra (Abelmoschus esculentus) when treated with hot water at $52^{\circ} \mathrm{C}$ for $30 \mathrm{~min}$. resulted in the improvement of crop, both in greenhouse and field conditions (Begum and Lokesh, 2012). Enotomo et al., (2002) described hot-water treatment as an alternative method to hypochlorite treatments for disinfecting pathogenic bacteria in seeds for alfalfa.

It may be concluded that hot water seed treatment at $53-55^{\circ} \mathrm{C}$ for $60 \mathrm{~min}$. can be effectively utilized in reducing the incidence of seed microflora and various seed borne diseases, but this temperature-time combination has subsequently increased ungerminated seed (\%) so hot water seed treatment at $50-52^{\circ} \mathrm{C}$ for $30 \mathrm{~min}$. could be considered as an holistic approach as it has reduced seed microflora and seed borne disease with least ungerminated seed $(\%)$.

\section{References}

Agarwal, A., Gupta, S. Ahmed, Z. 2007. Influence of plant densities on productivity of bell pepper (Capsicum annuum L.) under greenhouse in high altitude cold desert of Ladakh. Acta Horticulture, 756: 309-314.

Aguilar, G.A., Cruz, R. Baez, R. 1998. Storage Quality of Bell Peppers 
Pretreated with Hot Water and Polyethylene Packaging. Journal of Food Quality, 22: 287-299.

Aveling, T.A.S., Snyman, H.G., Maude, S.P. 1993. Evaluation of seed treatments for reducing Alternaria porri and Stemphylium vesicarium on onion seed. Plant Dis., 77: 1009.

Baker KF.1962. Thermotherapy of planting material. Phytopathology 52: 1244-1255

Begum, M., Lokesh, S. 2012. Effect of hot water and ultra violet radiation on the incidence of seedborne fungi of okra. Archives of Phytopathology and Plant Protection, 45: 126-132.

Collinge, B., Kragh, K.M., Mikkelsen, J.D., Nielsen, K.K., Rasmussen, U., Vad, K. 1993. Plant chitinases. Plant J., 3: 3140.

Enomoto, K., Takizawa, T., Ishikawa, N., Suzuki, T. 2002. Hot-Water Treatments for Disinfecting Alfalfa Seeds Inoculated with Escherichia coli ATCC25922. Food Science and Technology Research, 8(3): 247-251.

Floyd, R. 2005. Vegetable seed treatments, Farm note 90/190. Department of Agriculture and Food, Western Australia.

Gabrielson RL. 1983. Blackleg diseases of crucifers caused by Leptosphaeria maculans (Phoma lingam) and its control. Seed Science and Technology 11: 749-780.

Gupta, S.K., Thind, T.S. 2006. Disease problem in vegetable production, Scientific Publisher, pp. 342-346.

Hermansen, A., Brodal, G., Balvoll, G. 1999. Hot water treatments of carrot seeds: effects on seed-borne fungi, germination, emergence and yield. Seed Science and Technology 27(2): 599613.

Hoffmann GH, Nienhaus F, Schönbeck F, Weltzien H, Wilbert H.1994. Lehrbuch der Phytomedizin, Blackwell Wiss.
Verlag, Berlin.

Jach, G., Gornhardt, B., Mundy, J., Logemann, J. Pinsdorf, E., Leah, R., Schell, J., Maas, C. 1995. Enhanced quantitative resistance against fungal disease by combinatorial expression of different barley antifungal proteins in transgenic plants. Plant J., 8: 97-109.

Jahn M, Nega E, Werner. 2000. Pilzbefall an Gemüsesaatgut: Verträglichkeit und Wirkung der Heißwasserbehandlung. Gemüse 36: 17-19

Jensen JL. 1888. The propagation and prevention of smut in oats and barley. Journal of Royal Agricultural Society of England 24(2): 397-415.

Kauffmann, S., Legrand, M., Geoffroy, P., Friting, B. 1987. Biological function of 'pathogenesis-related' proteins. Four PR-proteins of tobacco have b-1,3glucanase activity. EMBO J., 6: 32093212.

Meah, M.B. 2004. Vegetable seed treating plant. USAID, Bangladesh Collaborative Research Project and IPM Lab. Dept. of Plant Pathology, BAU, Mymensingh.

Miller, S.A., Lewis Ivey, M.L. 2005. Hot water treatment of vegetable seeds to eradicate bacterial plant pathogens in organic production systems. The Ohio State University Extension, Columbus, $\mathrm{OH}$, Ohio state Extension Bulletin HYG-3086-05. Pp. 3.

Muniz, M.F.B. 2001. Control of microorganisms associated with tomato seeds using thermotherapy. Revista. Brassileira-sementes, 23(1): 176-280

Natzke E. 1997. Die Lagerung von Eicheln Situation, Versuche, Ausblick. In: Behandlung und Lagerung von Eichensaatgut. Mitteilungen aus der Biologischen Bundesanstalt für Landund Forstwirtschaft Berlin-Dahlem 329: 53-73

Nandini, R., Shripad Kulkarni. 2015. 
Evaluation of hot water treatment on seed germination and seedling infection of artificially inoculated cowpea seeds by Xanthomonas axonopodis pv. vignicola. International Journal of Bioassays, 4(8): 4181-4183.

Nega, E., Ulrich, R., Werner, S., Jahn, M. 2003. Hot water treatment of vegetable seed: An alternative seed treatment method to control seed-borne pathogens in organic farming. J. Plant Dis. Prot., 10: $220-234$.

Schlumbaum, A., Mauch, F., Vogeli, U., Boller, T. 1986. Plant chitinases are potent inhibitors of fungal growth. Nature, 324: 365- 367.

Temple, T.N., Toit, L.J., Derie, M.L., Johnson, K.B. 2013. Quantitative molecular detection of Xanthomonas hortorum pv. carotae in carrot seed before and after hot-water treatment. Plant Diseases, 97: 1585-1592.

Trueman SL, Wick RL.1996. Fusarium wilt of herbs. Acta Horticulturae 426: 365-
37

Walker JC. 1923. The hot water treatment of cabbage seed. Phytopathology 13: 251253

Van Loon, L.C., Van Strien, E.A. 1999. The families of pathogenesis related proteins, their activities, and comparative analysis of PR-1 type proteins. Physiol. Mol. Plant. Pathol., 55: 85-97.

Weiss, A., Hammes, W.P. 2005. Efficacy of heat treatment in the reduction of salmonellae and Escherichia coli O157: $\mathrm{H}-$ on alfalfa, mung bean and radish seeds used for sprout production. European Food Research and Technology, 221(1-2): 187-191.

Zhu, Q., Maher, E.A., Masoud, S., Dixon, R.A., Lamb, C.J. 1994. Enhanced protection against fungal attack by constitutive co-expression of chitinase and glucanase genes in transgenic tobacco. Biotechnology, 12: 807-812.

\section{How to cite this article:}

Suryapal Singh and Harshita Singh. 2020. Unclogging Seed Borne Pathogens to Prevent Diseases in Capsicum. Int.J.Curr.Microbiol.App.Sci. 9(05): 1871-1878. doi: https://doi.org/10.20546/ijcmas.2020.905.212 